\title{
Sublethal cellular effects of short-term raphidophyte and brevetoxin exposures on the eastern oyster Crassostrea virginica
}

\author{
Charles J. Keppler ${ }^{1, *}$, Alan J. Lewitus ${ }^{1,2}$, Amy H. Ringwood ${ }^{3}$, \\ Jennifer Hoguet ${ }^{4}$, Tracy Staton ${ }^{5}$ \\ ${ }^{1}$ Marine Resources Research Institute, South Carolina Department of Natural Resources, 217 Fort Johnson Road, \\ Charleston, South Carolina 29412, USA \\ ${ }^{2}$ Belle W. Baruch Institute for Marine and Coastal Sciences, University of South Carolina, PO Box 1630, \\ Georgetown, South Carolina 29442, USA \\ ${ }^{3}$ University of North Carolina-Charlotte, Department of Biology, 9201 University City Boulevard, Charlotte, \\ North Carolina 28223, USA \\ ${ }^{4}$ Center for Coastal Environmental Health and Biomolecular Research, National Ocean Service, NOAA, \\ 219 Fort Johnson Road, Charleston, South Carolina 29412, USA \\ ${ }^{5}$ Elizabeth City State University, 1704 Weeksville Road, Elizabeth City, North Carolina 27909, USA
}

\begin{abstract}
The susceptibility of shellfish to raphidophyte toxicity is not well resolved. This study examined the sublethal cellular responses of eastern oysters Crassostrea virginica exposed to 2 raphidophyte blooms (Chattonella subsalsa or Fibrocapsa japonica). Also, based on the hypothesis that raphidophyte toxicity is related to brevetoxin production, we determined the cellular responses of oysters to purified brevetoxin ( $\mathrm{PbTx}-3$ ) exposure in a separate experiment. We evaluated 3 cellular biomarkers, constituting both cellular damage and detoxification responses: lysosomal destabilization, lipid peroxidation and glutathione concentration. Exposing oysters to water collected from both blooms significantly increased lysosomal destabilization rates in oyster digestive gland when compared to controls, as did exposure to 1 and $10 \mathrm{nM} \mathrm{PbTx}-3$. Glutathione and lipid peroxidation levels were not significantly affected in any treatment. The physiological stress response (i.e. increased lysosomal destabilization rates) in oysters exposed to brevetoxin, C. subsalsa bloom water, or F. japonica bloom water is consistent with that found in oysters exposed to Heterosigma akashiwo (Raphidophyceae) blooms and cultures. The results indicate that oysters are susceptible to raphidophyte and brevetoxin toxicity, and are not solely a vector for neurotoxic shellfish poisoning. The common physiological response to raphidophyte and brevetoxin exposure is consistent with the hypothesized production of brevetoxin by this group, but alternatively may reflect a more general stress response in oysters.
\end{abstract}

KEY WORDS: Brevetoxin · Chattonella subsalsa Crassostrea virginica $\cdot$ Fibrocapsa japonica $\cdot$ Harmful algal bloom $\cdot$ Lysosomal destabilization $\cdot$ Raphidophyceae $\cdot$ Sublethal toxicity

\section{INTRODUCTION}

Raphidophytes are widely recognized as ichthyotoxic marine algae, and 6 species have been associated with finfish kills around the world. Chattonella antiqua/marina (H. A. Bowers unpubl. data), C. subsalsa, C. verruculosa, C. cf. verruculosa, Fibrocapsa japonica and Heterosigma akashiwo have been linked to mortalities of cultured and wild fishes in at least 12 countries (Landsberg 2002). The association of C. subsalsa, C. cf. verruculosa, F. japonica, and H. akashiwo with fish mortalities has recently been documented in several South Carolina brackish, stormwater-detention ponds and during a massive $H$. akashiwo bloom in Bulls Bay South Carolina (Lewitus et al. 2003, Keppler et al. 2005). 
The mechanism(s) of toxicity by this group are not fully agreed upon (Landsberg 2002). One proposed mechanism, the production of brevetoxin or brevetoxin-like compounds, has been demonstrated with laboratory cultures of Chattonella antiqua, Chattonella marina, Fibrocapsa japonica, and Heterosigma akashiwo (Ahmed et al. 1995, Khan et al. 1996a,b, 1997). Furthermore, Bourdelais et al. (2002) measured brevetoxin concentrations between 8 and $>200 \mathrm{ng} \mathrm{l}^{-1}$ in Delaware Inland Bays during a C. cf. verruculosa bloom (abundances ranged from $1.72 \times 10^{3}$ to $1.04 \times$ $10^{7}$ cells $\mathrm{ml}^{-1}$ ). Using the enzyme-linked immunosorbent assay (ELISA) described by Bourdelais et al. (2002), C. R. Tomas \& J. Naar (unpubl. data) measured brevetoxin or brevetoxin-like substances in water containing blooms of C. subsalsa, C. cf. verruculosa, F. japonica, and $H$. akashiwo collected from South Carolina brackish, stormwater-detention ponds (Lewitus \& Holland 2003, A. J. Lewitus \& A. F. Holland unpubl. data).

Brevetoxins are lipid-soluble polyether molecules that are readily accumulated and metabolized by bivalves (Baden 1989, Plakas et al. 2002). Because brevetoxins are responsible for neurotoxic shellfish poisoning (NSP) in humans, most research efforts have focused on the potential lethal effects on mammals, but little information is available on the sublethal cellular effects of brevetoxin exposure on the shellfish vectors of NSP. In Landsberg's (2002) compilation of the sublethal or chronic lethal effects of Karenia brevis on molluscs (their Table 9), only 2 studies were cited: Summerson \& Peterson (1990) for recruitment failure in Argopecten irradians (bay scallop), and Roberts et al. (1979) for loss of muscle control in Fasciolaria lilium hunteria (banded tulip), Melongena corona (crown conch) and Oliva sayana (lettered olive). In the latter study, exposure to $K$. brevis had no observable effect on Crassostrea virginica (eastern oyster).

In contrast to the cumulative evidence for pronounced ecological and economic impacts of raphidophyte blooms on finfish populations, their impacts on shellfish are likely to be sublethal and therefore less obvious and more difficult to detect and document. Keppler et al. (2005) used cellular biomarkers to assess the sublethal effects of Heterosigma akashiwo blooms and cultures on eastern oysters Crassostrea virginica. Exposure to the raphidophyte led to increased levels of lysosomal destabilization, a response indicative of cellular damage. In one experiment, lysosomal destabilization levels in oysters continued to increase after a $7 \mathrm{~d}$ depuration period that followed $4 \mathrm{~d}$ of exposure to H. akashiwo cultures. One implication was that shortterm exposure to $H$. akashiwo toxin may lead to a longer-term effect on hepatopancreatic function. This evidence for sublethal and possibly chronic responses of oysters to $H$. akashiwo underlines the importance of determining the mechanism of toxicity.
Sublethal effects of toxin exposure in oysters can be detected through the use of cellular biomarkers. The biomarkers evaluated in this study represent both cellular damage responses (lysosomal destabilization, lipid peroxidation) and a detoxification response (glutathione concentration). Lysosomes, typically involved in cellular defense, tissue repair and nutrition, can be adversely affected by exposure to a variety of stressors, including metals and polycyclic aromatic hydrocarbons (PAHs). Lysosomal membranes can be damaged (e.g. destabilized) such that the contents (characterized by low $\mathrm{pH}$ and various digestive enzymes) leak into the cytoplasm of the cell, which ultimately causes cell death (Regoli 1992, Lowe 1996). Lipid peroxidation occurs when free radicals react with the polyunsaturated lipids in cells and cell membranes, and is a source of cytotoxic products that may damage DNA and enzymes (Kehrer 1993). Increased lipid peroxidation has been demonstrated in response to metal and PAH exposures in a variety of organisms (Wofford \& Thomas 1988, Ringwood et al. 1998a). Glutathione (GSH) is an important overall modulator of cellular homeostasis, and serves numerous essential functions including detoxification of metals and oxy radicals (Meister \& Anderson 1983). There is evidence that GSH depletion is associated with exacerbation of adverse effects in marine bivalves as well as humans (Viarengo et al. 1990, Conners \& Ringwood 2000). Using these biomarkers, the overall purpose of this study was to determine the sublethal cellular effects of purified brevetoxin and raphidophyte bloom (Chattonella subsalsa, Fibrocapsa japonica) exposure on oysters.

\section{MATERIALS AND METHODS}

Bloom water. Bloom material was collected from surface waters of 2 brackish stormwater-detention ponds on Kiawah Island, South Carolina, on 8 June 2004 (K75 Pond, Chattonella subsalsa bloom, $30^{\circ} \mathrm{C}$, salinity 17.7, pH 8.85) and 11 August 2004 (K2 Pond, Fibrocapsa japonica bloom, $28.8^{\circ} \mathrm{C}$, salinity $28.4, \mathrm{pH} 8.78$ ). C. subsalsa abundance was estimated at $4.5 \times 10^{3}$ cell $\mathrm{ml}^{-1}$, and F. japonica abundance at $4.1 \times 10^{4} \mathrm{cell} \mathrm{ml}^{-1}$ (Table 1). The abundance of each species was approximately 5 to 6 times higher than the next most abundant species. Bloom water was stored in the laboratory in buckets at room temperature $\left(24^{\circ} \mathrm{C}\right)$ under overhead fluorescent lights.

Oyster collection. Oysters $(4.9 \pm 1.0 \mathrm{~cm})$ were collected from control sites in Clark Sound and Folly Beach, South Carolina, areas that have been shown to be unpolluted by metals or PAHs, based on extensive sediment contaminant analysis (Hyland et al. 1998, 
Table 1. Dominant phytoplankton taxa from Kiawah Island bloom samples used in this study

\begin{tabular}{|llc|}
\hline Bloom & Taxon & Cells ml $^{-1}$ \\
\hline K75 Pond (8 Jun 2004) & Chattonella subsalsa (Raphidophyceae) & 4532 \\
& Gymnodinium sp. (Dinophyceae) & 742 \\
& Gyrodinium spirale (Dinophyceae) & 268 \\
& Pfisteria-like organisms (Dinophyceae) & 227 \\
& Akashiwo sanguinea (Dinophyceae) & 41 \\
K2 Pond (11 Aug 2004) & Fibrocapsa japonica (Raphidophyceae) & 41365 \\
& Heterocapsa rotundata (Dinophyceae) & 8570 \\
& Anabaena sp. (Cyanobacteria) & 4450 \\
& Gymnodinium sp. (Dinophyceae) & 4450 \\
& Euglena sp. (Euglenophyceae) & 659 \\
\hline
\end{tabular}

Sanger et al. 1999a,b). Oysters were transported to the laboratory and held overnight in control site water. On the day of the exposure, the oysters were scrubbed clean and randomly placed in the treatments. An initial subset of oysters was dissected at the beginning of both the bloom-water exposure and the brevetoxin exposure periods to determine the cellular biomarker levels at Day zero.

Bloom-water exposure. Oysters were randomly placed into $3.5 \mathrm{l}$ control seawater (salinity adjusted to 25) and bloom-water treatments. Each treatment consisted of 3 replicates, with 6 oysters in each replicate. The water was renewed in all the containers after $48 \mathrm{~h}$, when $50 \%$ of the water was poured off and replaced with fresh filtered seawater (control treatments) or bloom water. At the end of the $96 \mathrm{~h}$ exposure, oyster digestive gland tissue was dissected out for immediate lysosomal destabilization analysis, and the remaining tissue was frozen at $-80^{\circ} \mathrm{C}$ for later analysis (digestive gland tissue for glutathione concentration and gill tissue for lipid peroxidation levels). To control against starvation stress responses, Isochrysis galbana (a nontoxic feeder algae cultured in the laboratory) was diluted to match the raphidophyte bloom abundances of each exposure (Table 1) and added to the control treatments. The decrease in abundance of Chattonella subsalsa (from $4.5 \times 10^{3}$ to 0 cells ml-1 $^{-1}$ and Fibrocapsajaponica (from $4.1 \times 10^{4}$ to $1.5 \times 10^{3}$ cells ml $^{-1}$ ) over the first $48 \mathrm{~h}$ exposure suggested that the raphidophytes were ingested by the oysters.

Brevetoxin exposure. Oysters were randomly placed in 3.51 control seawater (salinity adjusted to 25, with $0.02 \%$ acetone added to match the brevetoxin carrier solvent) and purified brevetoxin treatments. Each treatment consisted of 2 replicates, with 5 oysters in each replicate. The brevetoxin (PbTx-3; Calbiochem) concentration for an initial experiment was $0.1 \mathrm{nM}$, and a second experiment was performed with $\mathrm{PbTx}-3$ concentrations of 1.0 and $10 \mathrm{nM}$. The PbTx-3 form of brevetoxin was used for these experiments because it has been shown to be produced by Chattonella cf. verruculosa, (Bourdelais et al. 2002), and is suspected to be produced by Fibrocapsa japonica (Khan et al. 1996b). The water was renewed in all the containers every $24 \mathrm{~h}$, when $50 \%$ of the water was poured off and replaced with fresh filtered seawater and brevetoxin. At the end of the $72 \mathrm{~h}$ exposure, the oysters digestive gland tissue was dissected out immediate lysosomal destabilization analysis, and the remaining digestive gland tissue was frozen at $-80^{\circ} \mathrm{C}$ for lipid peroxidation and glutathione concentration analysis. Isochrysis galbana was added to all replicates daily. Both the bloom-water exposures and brevetoxin exposures were carried out at room temperature (approximately $24^{\circ} \mathrm{C}$ ).

Oyster biomarker assays. The lysosomal destabilization assay was conducted following the methods described in Ringwood et al. (1998b). Briefly, digestive gland tissue was homogenized, incubated on a shaker in calcium/magnesium-free saline (CMFS), disaggregated with trypsin, filtered (23 $\mu \mathrm{m}$ mesh) and centrifuged. The pellet was washed twice and resuspended in CMFS. This suspension was mixed 1:1 with a neutral red solution (NR) and incubated in a humidified chamber at room temperature for $1 \mathrm{~h}$. Digestive gland cells containing lysosomes were examined under a light microscope to evaluate NR retention. A minimum of 50 cells were scored as either stable (NR retention in the lysosomes) or destabilized (NR leaking into the cytoplasm), and the data were expressed as the percentage of cells with destabilized lysosomes per oyster.

The thiobarbituric acid-malondialdehyde (TBA) test was used to measure lipid peroxidation in oyster gill tissue (Gutteridge \& Halliwell 1990). Malondialdehyde (MDA) is a cellular byproduct commonly used to quantify lipid peroxidation. Gill tissues were homogenized in potassium phosphate buffer and centrifuged. A subsample of the supernatant was mixed with trichloroacetic acid containing TBA and butylated hydroxytoluene, heated for $15 \mathrm{~min}$ and centrifuged to remove the precipitate. The resulting MDA was detected at $532 \mathrm{~nm}$, and quantified using a standard curve.

Glutathione concentrations of individual oysters were determined using the enzymatic recycling assay (Anderson 1985, Ringwood et al. 1999), an assay that determines the rate of 5-thio-nitobenzoic acid (TNB) formation. Digestive gland tissues were homogenized in 10 volumes of $5 \%$ sulfosalicyclic acid and centrifuged. The supernatant was mixed 1:1 with reduced $\beta$-nicotinamide adenine di-nucleotide phosphate buffer 
containing 5,5'-dithiobis (2-nitrobenzoic acid). Glutathione reductase was added, and the rate of TNB formation was monitored at $405 \mathrm{~nm}$ over a $90 \mathrm{~s}$ interval. Glutathione concentrations were calculated from a standard curve.

The data were analyzed using Sigma Stat. Differences between treatments were examined using analysis of variance, with the Student-Newman-Keuls method used for multiple comparisons. To avoid statistical pseudoreplication, the mean measured value of the oysters within each replicate was treated as 1 sample value (therefore, $\mathrm{n}=3$ in the bloom-water exposures, and $n=2$ in the brevetoxin exposures).

\section{RESULTS AND DISCUSSION}

\section{Bloom-water exposures}

Exposure to Chattonella subsalsa or Fibrocapsa japonica bloom water caused a significant increase in lysosomal destabilization over a $96 \mathrm{~h}$ incubation that did not occur in control oysters (Figs. 1A \& 2A). Lysosomal destabilization rates in C. subsalsa bloom exposed oysters after $96 \mathrm{~h}$ were significantly higher than the Day zero oyster groups and the control oysters after $96 \mathrm{~h}(F=7.01, \mathrm{p}=0.009, \mathrm{df}=2)$. Lysosomal destabilization rates also were significantly higher in F. japonica bloom exposed oysters than the day zero oysters and the incubated control oysters $(F=22.88, \mathrm{p}<0.001, \mathrm{df}=$ 2). Neither lipid peroxidation levels (Figs. 1B \& 2B) nor glutathione levels (Figs. 1C \& 2C) were significantly affected by the short-term exposure to bloom water.

\section{Brevetoxin exposures}

Lysosomal destabilization significantly increased in oysters exposed for $72 \mathrm{~h}$ to 1 and $10 \mathrm{nM} \mathrm{PbTx}-3(F=$ 10.32, $\mathrm{p}<0.001, \mathrm{df}=4$ ) compared to the Day zero and control oysters (Fig. 3A). Neither lipid peroxidation levels (Fig. 3B) nor glutathione concentrations (Fig. 3C) were significantly affected by the short-term exposure to $\mathrm{PbTx}-3$. Oyster-tissue glutathione samples were processed for the $0.1 \mathrm{nM}$ brevetoxin exposure; however, the data are not presented in Fig. $3 \mathrm{C}$ because the standard values were well below our QA/QC (quality assurance/quality control) limit for the glutathione assay. Acetone, the carrier solvent included in the control treatments, did not have an effect on any of the oyster biomarker responses, as evidenced by the similar measurements between the Day zero and control oysters.

Lysosomal destabilization was previously demonstrated to be a sensitive biomarker of physiological
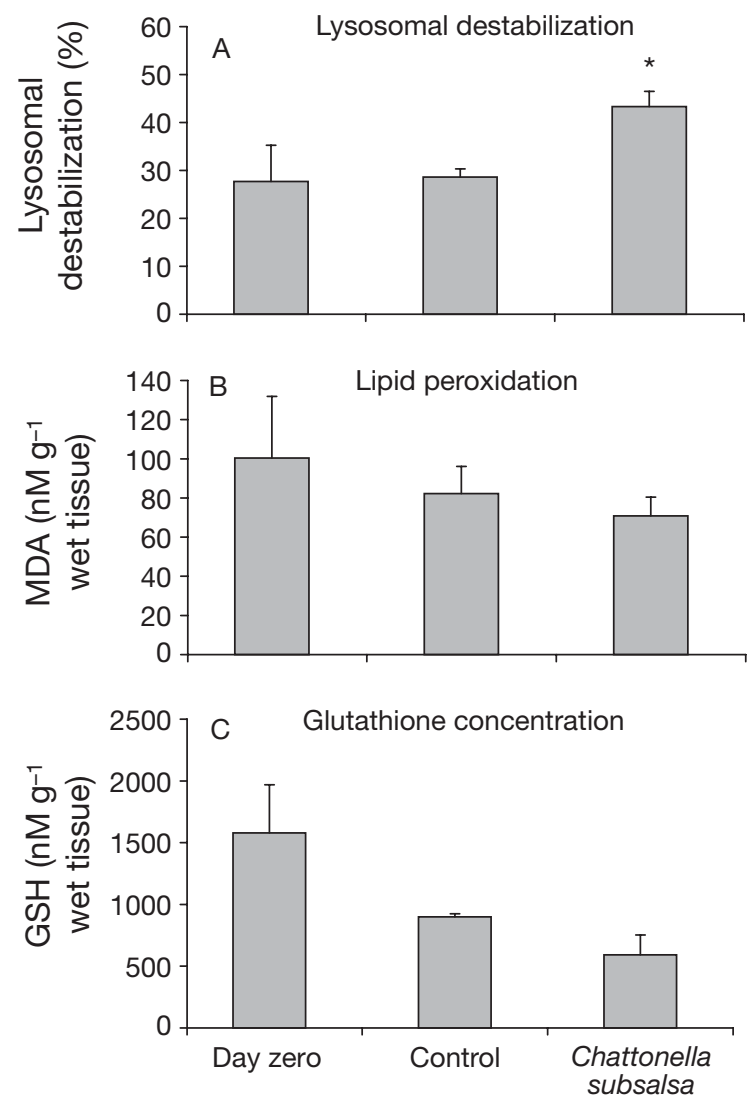

Fig. 1. Crassostrea virginica. Biomarker responses (mean $+\mathrm{SD}$ ) of oysters at start of incubation (Day zero) and after $96 \mathrm{~h}$ exposure to seawater control or to water containing a Chattonella subsalsa bloom. (A) Lysosomal destabilization; (B) lipid peroxidation (MDA: malondialdehyde); (C) glutathione (GSH) concentrations. *: significant difference from both initial (Day zero) and control oysters

stress in Crassostrea virginica (Ringwood et al. 1999). In the present study, short-term exposure to water samples collected during raphidophyte-dominated blooms and exposure to low concentrations of brevetoxin caused a significant increase in lysosomal destabilization. The levels measured in the brevetoxinexposed oysters (>38\% lysosomal destabilization) have been associated with significant impairment in digestive gland tissues (Ringwood et al. 2002). Moreover, recent studies have shown that parental rates of lysosomal destabilization $>35 \%$ are associated with the production of gametes with significantly reduced viability and poor rates of embryonic development (Ringwood et al. 2004). To date, increases in lysosomal destabilization to levels $>35 \%$ have been shown in oysters exposed to blooms of the raphidophytes Chattonella subsalsa and Fibrocapsa japonica (this study), and 2 blooms and a culture of Heterosigma akashiwo (Keppler et al. 2005). 

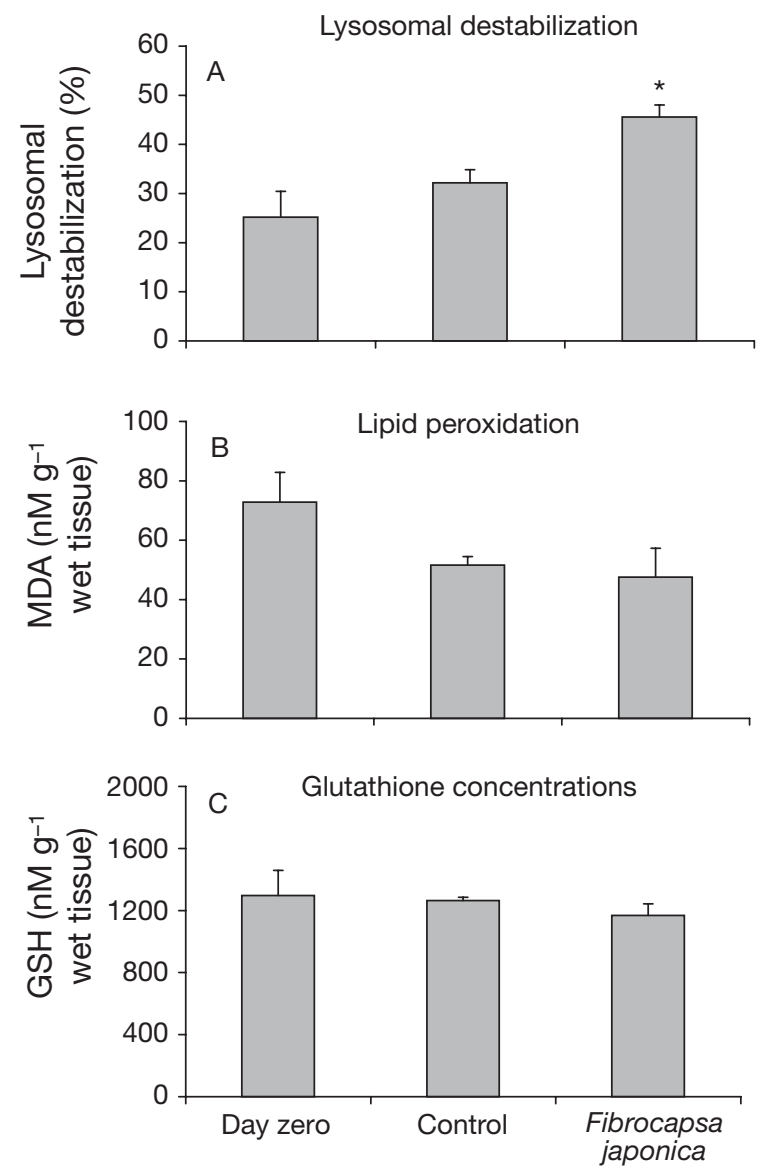

Fig. 2. Crassostrea virginica. Biomarker responses (mean $+\mathrm{SD}$ ) of oysters at start of incubation (Day zero) and after $96 \mathrm{~h}$ exposure to seawater control or to water containing a Fibrocapsa japonica bloom. Further details as for Fig. 1

The similarity in the lysosomal destabilization response of oysters exposed to raphidophytes and brevetoxin is consistent with the hypothesis that one of the mechanisms of raphidophyte toxicity is brevetoxin production, as concluded previously for Chattonella spp. (Khan et al. 1996a, Bourdelais et al. 2002), Fibrocapsa japonica (Khan et al. 1996b), and Heterosigma akashiwo (Black et al. 1991, Khan et al. 1997). Clearly, however, the similarity in raphidophyte- and brevetoxin-induced stress responses may be coincidental. Increased lysosomal destabilization in oysters can occur from metal (e.g. copper) or PAH exposure (Lowe et al. 1995, Ringwood et al. 1998b), and Lewitus et al. (2003) demonstrated the same stress response in oysters exposed to a bloom of Kryptoperidinium foliaceum (Dinophyceae). Therefore, lysosomal destabilization is a sensitive physiological indicator of several types of stressors, although these do not include such natural stressors as salinity (Ringwood et al. 1998b).

Lysosomal destabilization increased in a concentration-dependent manner in response to $\mathrm{PbTx}-3$ expo-
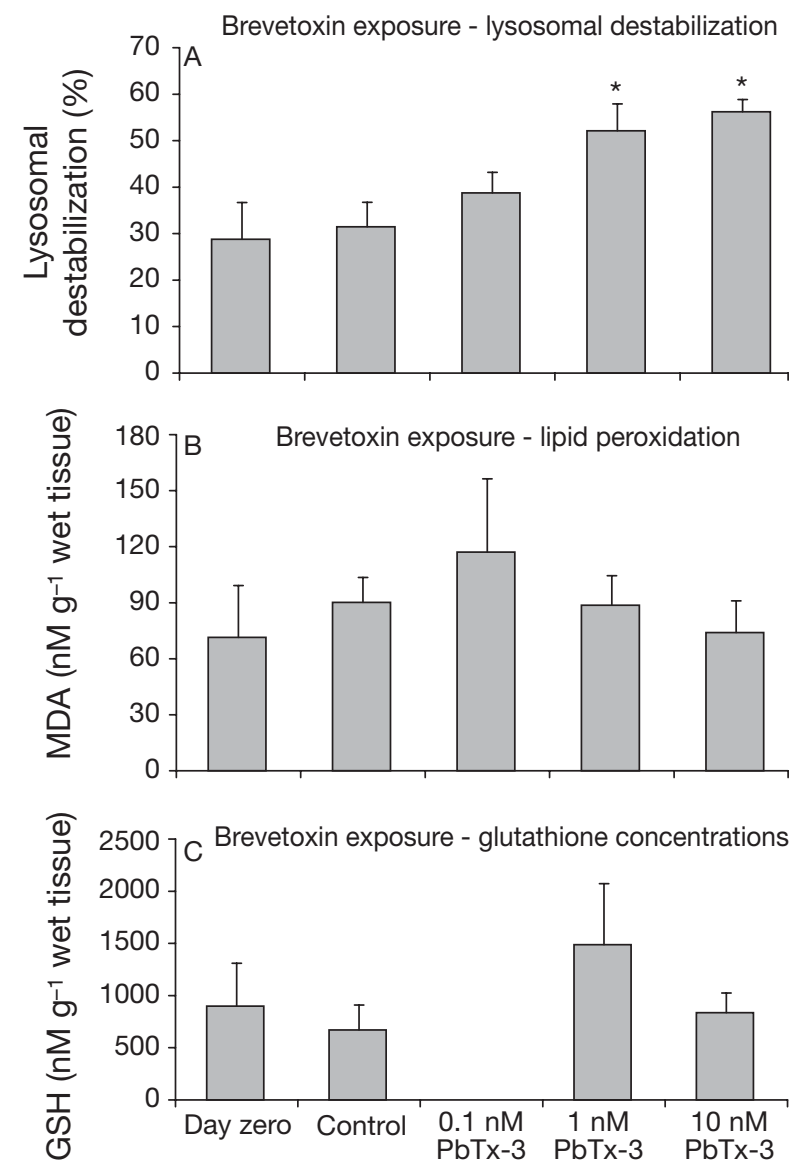

Fig. 3. Crassostrea virginica. Biomarker responses (mean $+\mathrm{SD}$ ) of oysters at start of incubation (Day zero) and after $72 \mathrm{~h}$ exposure to seawater control or to purified brevetoxin (PbTx-3). Further details as for Fig. 1

sure, with concentrations as low as $1.0 \mathrm{nM}$ causing a significant response. In comparison, Landsberg (2002) indicated an $\mathrm{LC}_{50}$ (lethal concentration) of 10 to $37 \mathrm{nM}$ for Type 1 brevetoxins (includes PbTx-3) based on $24 \mathrm{~h}$ mosquitofish Gambusia affinis assays (citing the work of Baden 1989, Baden et al. 1989). The 2 remaining oyster biomarkers, lipid peroxidation levels and glutathione concentrations, were unaffected by purified brevetoxin exposure and were well within the normal range for oysters collected from unpolluted control sites (A. H. Ringwood unpubl. data). In general, brevetoxin does not cause specific cell-membrane damage; it typically causes a change in cell-membrane polarization or an alteration in the sodium channel activity (Baden 1989). Therefore lipid peroxidation would not be expected to be increased in these short-term exposures. The detoxification response, glutathione concentration, may not have been affected for a number of reasons. Glutathione may not interact with a molecule as large as brevetoxin, or perhaps the experimental duration was not sufficient to elicit a response. Further 
studies, including longer-term exposures, are needed to answer these questions.

Although shellfish accumulation of brevetoxin is a well documented cause of neurotoxic shellfish poisoning (NSP) in humans, information is lacking on the toxic effects of brevetoxin on contaminated bivalves. In fact, in a literature review on harmful algal bloom effects on aquatic organisms, Landsberg (2002) cited only 4 cases of sublethal effects of Karenia brevis on molluscs. The present findings stress that research attention be directed not only to the role of shellfish as vectors of brevetoxin poisoning, but to the sublethal toxic effects of brevetoxin on shellfish populations.

In addition, our demonstrations of Chattonella subsalsa and Fibrocapsa japonica bloom effects on oyster lysosomal destabilization extend findings of similar stress responses following Heterosigma akashiwo and Kryptoperidinium foliaceum bloom exposure (Lewitus et al. 2003, Keppler et al. 2005). These species commonly form blooms in South Carolina waters where oyster and other shellfish exposure is pervasive. For example, the most common harmful algal species in South Carolina tidal creeks is K. foliaceum, which has formed blooms from northern to southern reaches of the South Carolina coast (Lewitus \& Holland 2003). From 2001 to 2004, raphidophytes were found in 50\% of the $>1000$ South Carolina brackish detention-pond samples collected, and often blooms found in the ponds were associated with similar abundances in the adjacent tidal creeks exchanging water with the ponds (Lewitus et al. 2004). Research is needed into the physiological condition of shellfish potentially experiencing chronic stress from repetitive exposure to harmful algal blooms.

Acknowledgements. We thank P. Brown, K. DeMattio, S. Habrun, J. Kempton, L. Mason, J. Rudisill, P. Williams and S. Wilde for their assistance in the laboratory and the field. This research was supported in part by the South Carolina Department of Natural Resources' Minority in Marine Environmental Sciences summer internship program, US ECOHAB Program (sponsored by NOAA/NSF/EPA/ NASA/ONR) grant NA16OP2796, NOAA grant NA06OA0675 and CDC grant V2C6. This is contribution 568 of SCDNR's Marine Resources Research Institute, contribution 1422 of USC's Belle W. Baruch Institute, and ECOHAB contribution 167.

\section{LITERATURE CITED}

Ahmed MS, Kahn S, Arakawa O, Onoue Y (1995) Properties of hemaglutins newly separated from toxic phytoplankton. Biochem Biophys Acta 1243:509-512

Anderson ME (1985) Determination of glutathione and glutathione disulfide in biological samples. Meth in Enzymol 113:548-555

Baden DG (1989) Brevetoxins: unique polyether dinoflagellate toxins. FASEB J 3:1807-1817

Baden DG, Mende TJ, Szmant AM, Trainer VL, Edwards RA
(1989) Brevetoxin binding to rat brain synaptosomes: inhibition constants of derivative brevetoxins. In: Okaichi $\mathrm{T}$, Anderson DM, Nemoto T (eds) Red tides: biology, environmental science and toxicology. Elsevier, New York, p 431-434

Black EA, Whyte JNC, Bagshaw JW, Ginther NG (1991) The effects of Heterosigma akashiwo on juvenile Oncorhynchus tshawytscha and its implication for fish culture. J Appl Ichthyol 7:168-175

Bourdelais AJ, Tomas CR, Naar J, Kubanek J, Baden DG (2002) New fish-killing alga in coastal Delaware produces neurotoxins. Environ Health Perspect 110:465-470

Conners DE, Ringwood AH (2000) Effects of glutathione depletion on copper cytotoxicity in oysters (Crassostrea virginica). Aquat Toxicol 50:341-349

Gutteridge JMC, Halliwell B (1990) The measurement and mechanism of lipid peroxidation in biological systems. TIBS (Trends Biochem Sci) 15:129-135

Hyland JL, Balthis L, Hackney CT, McRae G, Ringwood AH, Snoots TR, Van Dolah RF, Wade TL (1998) Environmental quality of estuaries of the Carolinian Province: 1995. NOAA Tech Mem NOS ORCA 123. NOAA/NOS, Office of Ocean Resources Conservation and Assessment, Silver Springs, MD

Kehrer JP (1993) Free radicals as mediators of tissue injury and disease. Crit Rev Toxicol 23:21-48

Keppler CJ, Hoguet J, Smith K, Ringwood AH, Lewitus AJ (2005) Sublethal effects of the toxic alga Heterosigma akashiwo on the southeastern oyster (Crassostrea virginica). Harmful Algae 4:275-285

Khan S, Arakawa O, Onoue Y (1996a) A toxicological study of the marine phytoflagellate, Chattonella antiqua (Raphidophyceae). Phycologia 35:239-244

Khan S, Arakawa O, Onoue Y (1996b) Neurotoxin production by a chloromonad, Fibrocapsa japonica (Raphidophyceae). J World Aquac Soc 27:254-263

Khan S, Arakawa O, Onoue Y (1997) Neurotoxins in a toxic red tide of Heterosigma akashiwo (Raphidophyceae) in Kagoshima Bay, Japan. Aquac Res 28:9-14

Landsberg JH (2002) The effects of harmful algal blooms on aquatic organisms. Rev Fish Sci 10:113-390

Lewitus AJ, Holland AF (2003) Initial results from a multiinstitutional collaboration to monitor harmful algal blooms in South Carolina. Environ Monit Assess 81:361-371

Lewitus AJ, Schmidt LB, Mason LJ, Kempton JW and 7 others (2003) Harmful algal blooms in South Carolina residential and golf course ponds. Popul Environ 24:387-413

Lewitus AJ, Hayes K, Kempton J, Mason L, Wilde S, Williams B, Wolny J (2004) Prevalence of raphidophyte blooms in South Carolina brackish ponds associated with housing and golf courses. In: Steidinger KA, Landsberg JA, Tomas CR, Vargo GA (eds) Proc 10th Int Conf on harmful algae. Florida Fish and Wildlife Conservation Commission, St. Petersburg, FL, p 350-352

Lowe DM (1996) Mechanisms of toxicity in molluscan lysosomes. Mar Environ Res 42:109

Lowe DM, Fossato VU, Depledge MH (1995) Contaminantinduced lysosomal membrane damage in blood cells of mussels Mytilus galloprovincialis from the Venice lagoon: an in vitro study. Mar Ecol Prog Ser 129:189-196

Meister A, Anderson ME (1983) Glutathione. Annu Rev Biochem 52:711-760

Plakas SM, El Said KR, Jester ELE, Granade HR, Musser SM, Dickey RW (2002) Confirmation of brevetoxin metabolism in the eastern oyster (Crassostrea virginica) by controlled exposures to pure toxins and to Karenia brevis cultures. Toxicon 40:721-729 
Regoli F (1992) Lysosomal responses as a sensitive stress index in biomonitoring heavy metal pollution. Mar Ecol Prog Ser 84:63-69

Ringwood AH, Conners DE, Dinovo A (1998a) The effects of copper exposures on cellular responses in oysters. Mar Environ Res 46:591-595

Ringwood AH, Conners DE, Hoguet J (1998b) Effects of natural and anthropogenic stressors on lysosomal destabilization in oysters Crassostrea virginica. Mar Ecol Prog Ser 166:163-171

Ringwood AH, Conners DE, Keppler CJ (1999) Cellular responses of oysters, Crassostrea virginica, to metal contaminated sediments. Mar Environ Res 48:427-437

Ringwood AH, Hoguet J, Keppler CJ (2002) Seasonal variation in lysosomal destabilization in oysters, Crassostrea virginica. Mar Environ Res 54:793-797

Ringwood AH, Hoguet J, Keppler CJ, Gielazyn M (2004) Linkages between cellular biomarker responses and reproductive success in oysters-Crassostrea virginica. Mar Environ Res 58:151-155

Roberts BS, Henderson GE, Medlyn RA (1979) The effect of Gymnodinium breve toxin(s) on selected mollusks and

Editorial responsibility: Howard I. Browman (Associate Editor-in-Chief), Storebø, Norway crustaceans. In: Taylor DL, Seliger HH (eds) Toxic dinoflagellate blooms. Elsevier, New York, p 419-424

Sanger DM, Holland AF, Scott GI (1999a) Tidal creek and salt marsh sediments in South Carolina coastal estuaries. I. Distribution of trace metals. Arch Environ Contam Toxicol 37:445-457

Sanger DM, Holland AF, Scott GI (1999b) Tidal creek and salt marsh sediments in South Carolina coastal estuaries. II. Distribution of organic contaminants. Arch Environ Contam Toxicol 37:458-471

Summerson HC, Peterson CH (1990) Recruitment failure of the bay scallop, Argopecten irradians concentricus, during the first red tide, Ptychodiscus brevis, outbreaks recorded in North Carolina. Estuaries 13:322-331

Viarengo AL, Canesi L, Pertica M, Poli G, Moore MN, Orunesu M (1990) Heavy metal effects on lipid peroxidation in the tissues of Mytilus galloprovincialis Lam. Comp Biochem Physiol C 97:32-42

Wofford HW, Thomas P (1988) Peroxidation of mullet and rat liver lipids in vitro: effects of pyridine nucleotides, iron, incubation buffer, and xenobiotics. Comp Biochem Physiol C 89:201-206

Submitted: June 6, 2005; Accepted: September 27, 2005

Proofs received from author(s): March 3, 2006 